ISSN 1392-3196 / e-ISSN 2335-8947

Zemdirbyste-Agriculture, vol. 102, No. 4 (2015), p. 449-456

DOI $10.13080 / \mathrm{z}-\mathrm{a} .2015 .102 .058$

\title{
Efficiency of a computerised decision support system as a tool to reduce fungicide input for the control of potato late blight
} \author{
Antanas RONIS ${ }^{2}$, Harold W. (Bud) PLATT ${ }^{3}$ \\ ${ }^{1}$ All-Russian Research Institute of Phytopathology \\ Institute 5, Bolshie Vyazemy, Moscow region, 143050 Russia \\ E-mail: filippov@vniif.ru \\ ${ }^{2}$ Institute of Agriculture, Lithuanian Research Centre for Agriculture and Forestry \\ Instituto 1, Akademija, Kèdainiai distr., Lithuania \\ ${ }^{3}$ Crops and Livestock Research Centre, Agriculture and Agri-Food Canada \\ 440 University Avenue, Charlottetown, Prince Edward Island C1A 4N6, Canada
}

Alexey FILIPPOV ${ }^{1}$, Alexander ROGOZHIN ${ }^{1}$, Maria KUZNETSOVA ${ }^{1}$, Natalia STATSYUK ${ }^{1}$,

\begin{abstract}
The VNIIFBlight decision support system is intended to identify weather conditions favourable or unfavourable for the late blight outbreaks on potato. To provide an improved choice of fungicide treatment dates, we investigated the use of a standard five-day weather forecast based disease management decision support system VNIIFBlight as well as the use of information about the late blight resistance level of the cultivars used. The efficiency of this decision support system was compared with a seven-day routine program of fungicide treatments in the course of four-year field trials in Moscow region and six-year "virtual" trials in four regions of Russia, three regions of Lithuania, and single regions of Canada, Ukraine, Poland, and the Netherlands.

According to the results of field experiments, in the case of a high infection pressure (2004 and 2008), yield losses caused by late blight in the untreated control made up $62 \%$ and $39 \%$, respectively, whereas the losses for both compared schemes of protection did not exceed $8.2 \%$ for both years. In the case of weak disease development (2005 and 2007), for all studied treatments, including the untreated control, yield losses did not exceed 3\%. In all years, the use of the VNIIFBlight decision support system significantly reduced the number of fungicidal treatments as compared to the routine scheme of protection; this reduction in 2004, 2005, 2007 and 2008 made up 62, 50, 50 and $17 \%$, respectively.

According to the results of "virtual" trials, the use of the VNIIFBlight decision support system reduced the number of fungicide treatments of susceptible and resistant potato cultivars by $50 \%$ and $60 \%$ on average, respectively, as compared with the routine program.
\end{abstract}

Key words: fungicide application, mathematical model, Phytophthora infestans.

\section{Introduction}

Potato is one of the most important strategic foods in many regions of the world. Food security of millions of rural and urban families significantly depends on this agricultural crop. Causal agents of various potato diseases represent a significant factor reducing the productivity and quality of potato. In the majority of potato-growing regions, the most important and devastating disease is late blight caused by the oomycete Phytophthora infestans (Mont.) de Bary. For example, even under the current production methods and protective strategies used in the United Kingdom, late blight causes the largest losses in potential yield and quality of potato with an annual industry value of about 55 million pounds. Without any fungicidal treatment, the late blight-caused losses would reach 363 million pounds that would make almost half of the total production (Twining et al., 2009).
The average annual potato losses caused by this disease in Russia reach 4 million tons, but during epidemics and with the absence of any disease control, potato production is reduced almost twice (Filippov, 2012). According to the data obtained in Lithuania, late blight-caused yield losses in this country amount to $20-30 \%$; under favourable weather conditions they can be even higher (Ronis, Tamošiūnas, 2005; Runno-Paurson et al., 2015).

Potato late blight can be managed either via the application of fungicides or via the deployment of the late blight resistance in potato cultivars.

In terms of fungicide usage, potato growers in the more advanced potato-producing countries, such as the Netherlands, United Kingdom, Belgium, and France, apply 12-19 fungicide treatments each growing season (Hansen et al., 2009; 2014). In Russian Federation, 
the average number of such spray applications is 4-6 per season for small farms and 9-11 for large potatogrowing companies. An adverse effect of such approach is environmental pollution. It is known that pesticide residues in vegetable plants and soil are able to pose a threat for both human health and the environment. Potato is one of the agricultural crops which contamination with pesticide residues is hazardous to the environment and humans (Benbrook et al., 2002). Among the 27 fungicides applied in Russia to prevent the late blight infection during the plant vegetation, 14 contain mancozeb or other dithiocarbamates. When these fungicides get into the soil and come into contact with water and oxygen, their active compounds degrade into ethylene thiourea; this compound has a carcinogenic and mutagenic effect and causes endocrine disorders in laboratory animals (Shykla, Arora, 2001). There are some other active ingredients applied in potato in Russia which are also considered hazardous for human health and environment (Twining et al., 2009). The negative influence of fungicides on the human health and environment and their high cost have resulted in the need to search for new technologies which would provide a significant reduction of the use of fungicidal treatments of potato while maintaining acceptable potato production and quality levels.

In terms of the use of resistant cultivars, it is possible to either reduce the dosage of active ingredients applied at standard intervals or increase the interval between treatments with a standard amount of an active ingredient. Studies performed in the USA (Fry, 1978) and the Netherlands (Spits et al., 2007; Kessel et al., 2010) demonstrated that the applied dosage of fungicides should vary depending on the late blight resistance level of a cultivar used. Susceptible cultivars should be treated with the maximum recommended dosage of a fungicide, whereas the dosage for moderately resistant cultivars should be reduced by $25-50 \%$ (Fry et al., 1983). According to Russian legislation, one can increase spraying intervals but cannot increase or decrease the recommended fungicidal dosages regardless of cultivar resistance or susceptibility levels.

To assess the expediency of fungicide applications, one should foresee not only changes in the disease dynamics caused by such treatment but also the effect on potato yield and quality. Potato treatment with fungicides should not be considered as an end in itself. If late blight appears later, or the severity of the disease is low, such treatments could be unprofitable, since their cost will not be compensated with the profit of the obtained yield increase. The same situation is possible in the case of repeated treatments, if previous treatments successfully suppressed disease development, and the harvesting is planned early. Thus, there are some situations in which protective treatments of potato are unprofitable even in spite of their high technical efficiency. Therefore, financial losses can be caused either by yield losses, or by uncompensated chemical protection costs.

The most important question, usually asked by potato producers, is "What conditions are the most suitable for a fungicide treatment?" It is known that fungicides necessary to control late blight are effective only if they are applied shortly before the time of infection (Bǿdker, Nielsen, 2001). Many studies performed in advanced potato-producing countries were intended to optimize the number of fungicide treatments using various decision support systems (DSS) where every treatment is determined by using meteorological data and mathematical simulators of a disease development (Schepers et al., 2009; Kessel et al., 2010; Nielsen et al., 2010). Now the total number of DSS used in different countries is about 20. The most popular systems are NegFry, SimPhyt, Plant-Plus, ProPhy, Guntz-Divoux, Milsol, PhytoPre+2000 and China-blight (Schepers, 2004; Wander et al., 2006; Small et al., 2013; Hu et al., 2014). The use of DSS in some European countries reduced fungicide application by $8-62 \%$ as compared with a routine scheme of treatments; these results were confirmed in 26 of 29 tests (Schepers, 2004).

The decision support system VNIIFBlight, developed for Russian potato-growers by the experts of the All-Russian Research Institute of Phytopathology, makes it possible to choose the mode of fungicide treatments in accordance with the cultivar resistance and weather conditions (Filippov et al., 2009). The development of this decision support system was motivated by the fact that many potato-producing regions are located in climatic zones, where the frequency of late blight epidemics is less than $50 \%$. It is clear that the routine scheme with fixed seven-day intervals between fungicide treatments is justified only for climatic zones with a high epidemic risk, whereas in other regions it is unprofitable. To create the decision support system able to determine meteorological conditions important for the disease development, a special long-term study was carried out in different climatic regions (Moscow region and Far East (Russia), Georgia and Estonia). It was shown that the late blight development during a growing season consists of some separate (sporadic) outbreaks, each resulting from the re-infection of potato plants. Such re-infection took place when meteorological conditions were favourable for the formation of sporangiophores and sporangia, spreading and survival of sporangia, and zoospore formation and penetration into leaf tissues. According to the results obtained, all days of a growing season were divided into two groups. The first one included days, when re-infection provided the outbreak of the disease (136 cases). The second group included all other days (150 cases). Based on these results, a mathematical simulator has been developed, which identified the type of weather, favourable or unfavourable for the late blight outbreaks on the potato foliage. To provide a preliminary determination of "risky" days and recommended dates for a fungicide treatment, we followed a standard fiveday weather forecast (Starodub, Gurevich, 1989; Filippov et al., 2009). Predicted weather conditions are evaluated using the following two equations:

$$
\begin{array}{r}
\mathrm{y}_{1}=-32.47+0.75 \mathrm{x}_{1}+0.41 \mathrm{x}_{2}+0.41 \mathrm{x}_{3}+0.27 \mathrm{x}_{4} \\
+0.74 \mathrm{x}_{5}+0.30 \mathrm{x}_{6}-0.07 \mathrm{x}_{7}-0.16 \mathrm{x}_{8}+0.06 \mathrm{x}_{9}+0.01 \mathrm{x}_{10}+ \\
2.88 \mathrm{x}_{11}+1.98 \mathrm{x}_{12}+1.98 \mathrm{x}_{13}+1.79 \mathrm{x}_{14}+0.53 \mathrm{x}_{15}
\end{array}
$$

$$
\mathrm{y}_{2}=-31.34+0.63 \mathrm{x}_{1}+0.37 \mathrm{x}_{2}+0.42 \mathrm{x}_{3}+0.22 \mathrm{x}_{4}
$$
$+0.65 \mathrm{x}_{5}+0.24 \mathrm{x}_{6}-0.06 \mathrm{x}_{7}-0.15 \mathrm{x}_{8}-0.13 \mathrm{x}_{9}+0.15 \mathrm{x}_{10}+$ $4.88 \mathrm{x}_{11}+3.55 \mathrm{x}_{12}+3.34 \mathrm{x}_{13}+2.50 \mathrm{x}_{14}+2.29 \mathrm{x}_{15}$

where $x_{1,2,3,4,5}$ and $x_{6,7,8,9,10}$ are daily and night temperatures $\left({ }^{\circ} \mathrm{C}\right)$, respectively, and $\mathrm{x}_{11,12,13,14,15}$ describe precipitation occurred in the $1^{\text {st }}, 2^{\text {nd }}, 3^{\text {rd }}, 4^{\text {th }}$ and $5^{\text {th }}$ days, respectively (yes/no). 
Equations 1 and 2 describe conditions, which are unfavourable or favourable for the re-infection of potato plants, respectively. If $\mathrm{y}_{1}<\mathrm{y}_{2}$, a fungicide treatment is recommended. The forecast for the first treatment starts when the height of plants reaches $20-30 \mathrm{~cm}$. If the resistance of the potato cultivar does not exceed 5 scores (according to a 9-score scale, where 9 means the maximum resistance to late blight), it is recommended to repeat the treatment according to the weather forecast, but at least 6-7 days after the previous treatment. For potato cultivars which late blight resistance reaches 5 scores or more, the repeated treatment should be carried out at least 10-11 days after the previous one.

The online calculator for the evaluation of the weather conditions (Fig.) is available at $<$ http://vniif.ru/ vniif.fitoftora/index en.html $>$.

The purpose of this study was to compare the efficiency of the decision support system VNIIFblight recommendations with a routine scheme of a fungicide application (treatment every 7 days irrespective of the weather and the late blight resistance of the cultivars used). A comparison was carried out under field and "virtual" conditions

\section{Materials and methods}

Field trials. Field trials were carried out at the experimental field of the All-Russian Research Institute of Phytopathology (Bolshie Vyazemy, Moscow region) during four growing seasons (2004, 2005, 2007 and 2008). The weather conditions of these seasons are shown in Figure. In these trials, the following treatments were compared: 1) routine scheme of a fungicide application (the treatment is carried out every 7 days irrespective of the weather and the late blight resistance of the cultivars used); 2) decision support system VNIIFBlight (the treatment is carried out based on decision support system VNIIFBlight recommendations); and 3) control (no fungicide treatments).

Potato cultivars used in the trials were 'Sante' (2004-2005) and 'Red Scarlett' (2007-2008).

Fungicide treatments included the spraying of plants with fluazinam-containing fungicide (Shirlan) at a dose rate of $0.41 \mathrm{ha}^{-1}$. Both fungicide application schemes started when the height of plants reached $25-30 \mathrm{~cm}$. Fertilizers were applied in the following way: nitrogen at a dose rate of $220 \mathrm{~kg} \mathrm{ha}^{-1}$ (with an allowance for the nitrogen amount already presenting in soil); $\mathrm{P}_{2} \mathrm{O}_{5}$ and $\mathrm{K}_{2} \mathrm{O}$ at dose rates of 140 and $240 \mathrm{~kg} \mathrm{ha}^{-1}$, respectively. Nitrogen was applied twice: before the planting (2/3 of the total dosage) and in the beginning of a tuber formation stage $(1 / 3)$.

Field trials were arranged in four replications using a completely randomized block design. The area of each four-row plot was $36 \mathrm{~m}^{2}$. Potatoes were planted in the second week of May. Seed spacing was approximately $30 \mathrm{~cm}$ with $70-\mathrm{cm}$ row width. A desiccant (diquat) was applied in the second-third week of August, and potatoes were harvested 10-14 days later.

During the growing season, the disease level was evaluated weekly using the foliage blight assessment key of the British Mycological Society (Cox, Large, 1960). The severity of the foliar blight infection was expressed as a percentage of yield losses, caused by the death of infected leaves (Gurevich et al., 1977). This method of analysis is based on the Van der Plank (1963) hypothesis assuming a direct relation between the area under the disease progress curve (AUDPC), describing the seasonal dynamics of the disease, and the yield loss. The yield loss is expressed by the following equation: $\omega=(\mathrm{AUDPC} / q) \times 100(3)$, where $\omega$ is a yield loss $(\%)$ caused by a premature leaf death, and $q$ is the number of days between a bud formation stage and the die-off of non-infected leaves. The average $q$ values for early, intermediate, and mid-late potato cultivars are 46,52 and 84 days, respectively. If the foliage is killed by frost or any reasons other than the late blight development, $q$ is considered as the number of days between the bud formation stage and the moment of the foliage death.

To assess the tuber blight infection severity, two central rows of each plot were completely harvested and tubers were put for one-month storage at $3^{\circ} \mathrm{C}$. After the end of this period, tubers in each sample were washed and divided into healthy and blighted fractions. Both fractions were weighed. The total severity of the tuber blight infection was expressed as a percentage of blighted tubers.

The yield losses and severity of the tuber blight infection, shown in Table 1, were analyzed by the LSD test $(p=0.05)$ as described by Dospekhov (1984).

"Virtual" trials. The purpose of the two "virtual" trials was to assess how the use of the decision support system VNIIFBlight may influence the frequency of fungicide application in different seasons within one geographic region and in different regions within one season.

In the first trial, we used a retrospective analysis of meteorological data within six seasons to calculate the number of fungicide applications required according to the decision support system VNIIFBlight in Russia (Moscow, Kaliningrad, Kazan and Vologda regions) and Lithuania (Vilnius, Kaunas and Dotnuva regions). The calculations were made for the period from June 15 to August 5 for two abstract groups of potato cultivars differing in the late blight resistance index $(<5$ or $\geq 5)$. It was considered that the repeated spraying of potato plants from the first and second group of cultivars was carried out at least 7 or 11 days after the previous spraying, respectively, even in the case of critical (according to the decision support system VNIIFBlight) conditions.

In the second trial we monitored a 5-day weather forecast between 15 June, 2014 and 5 August, 2014 in the following 10 regions: Tumen, Kazan, Moscow, Bryansk and Yuzhno-Sakhalinsk (Russia), Kiev (Ukraine), Warsaw (Poland), Lelystad (Netherlands) and Charlottetown (Canada). Based on the obtained data, we used the decision support system VNIIFBlight to calculate the recommended dates of fungicide applications for each region. The calculations were performed separately for two above-mentioned groups of potato cultivars and two potato-growing technologies (no irrigation and irrigation by sprinkling every 5 days; the days of irrigation were considered as rainy days).

In both "virtual" trials the results of the use of the decision support system VNIIFBlight were compared with the routine fungicide application scheme (treatments every 7 days). 

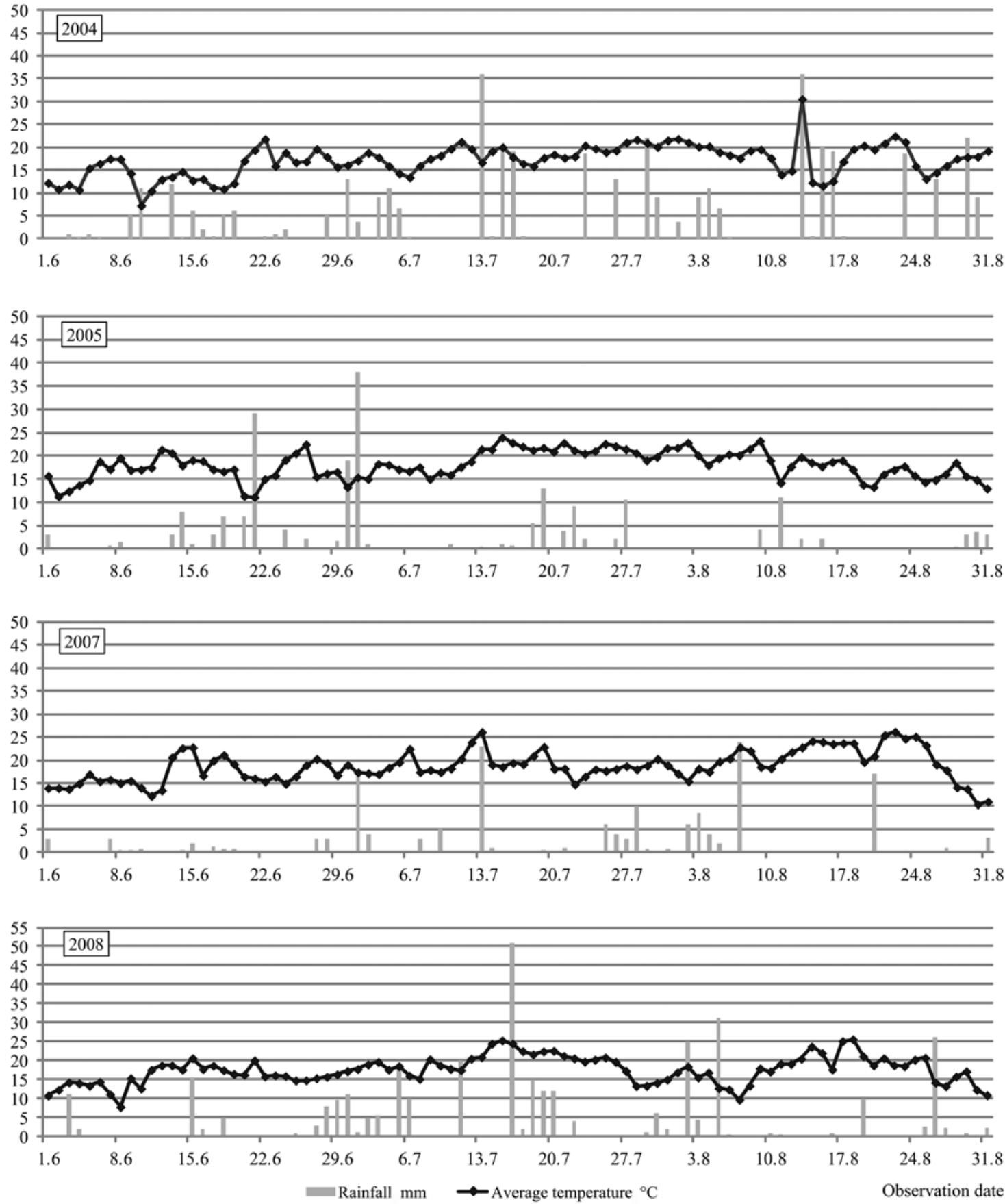

Figure. Average temperature and precipitation during field trials performed in Moscow region in 2004, 2005,2007 and 2008

\section{Results and discussion}

Field trials. The results of the field trials are shown in Table 1. The compared growing seasons demonstrated a clear contrast in the disease development. The amount of rainfall in June-August of 2004, 2005, 2007 and 2008 was equal to 410, 207, 164 and $342 \mathrm{~mm}$, respectively (Fig.); that provided very high late blight pressure in 2004 and 2008. Due to the rainy weather, a rapid disease development occurred in the untreated plots (control); the total infection of foliage was observed long before the natural leaf decay. As a result, yield losses in the control plots made up $62 \%$ and $39 \%$ in 2004 and 2008, respectively. However, a very rapid desiccation of infected foliage in 2004 resulted in a low tuber infection level. On the contrary, tuber blight frequency in the control plots was rather high in 2008 (16.4\%). As seen in Table 1, both tested programs provided an acceptable level of the late blight control in the case of a severe disease development. In 2004 and 2008, no difference was observed between the routine scheme and VNIIFBlight recommendations. The use of both programs significantly reduced yield losses caused by the foliage blight. Similarly, in 2008 both programs significantly reduced the percentage of infected tubers compared to the untreated control. However, in 2004 and 2008 the use of the decision support system VNIIFBlight recommendations reduced the use of fungicide by $62.5 \%$ and $16.7 \%$, respectively, as compared to the routine program of treatment. 
Table 1. The effect of the decision support system VNIIFBlight and routine programs of fungicide treatments on the manifestation of potato late blight infection

\begin{tabular}{|c|c|c|c|c|}
\hline Year & $\begin{array}{c}\text { Fungicide treatment } \\
\text { program }\end{array}$ & $\begin{array}{l}\text { Rated yield loss caused } \\
\text { by the foliar blight } \%\end{array}$ & $\begin{array}{c}\% \text { of infected } \\
\text { tubers }\end{array}$ & $\begin{array}{c}\text { Number of fungicide } \\
\text { treatments }\end{array}$ \\
\hline \multirow{3}{*}{2004} & Routine & $2.6 \mathrm{a}^{*}$ & $1.4 \mathrm{a}$ & 8 \\
\hline & VNIIFBlight & $8.2 \mathrm{a}$ & $2.9 \mathrm{a}$ & 3 \\
\hline & Untreated control & $62.0 \mathrm{~b}$ & $2.1 \mathrm{a}$ & 0 \\
\hline \multirow{3}{*}{2005} & Routine & $<1 \mathrm{a}$ & 0 & 6 \\
\hline & VNIIFBlight & $<1 \mathrm{a}$ & 0 & 3 \\
\hline & Untreated control & $2.1 \mathrm{a}$ & 0.1 & 0 \\
\hline \multirow{3}{*}{2007} & Routine & $<1 \mathrm{a}$ & $0.5 \mathrm{a}$ & 6 \\
\hline & VNIIFBlight & $<1 \mathrm{a}$ & $0.6 \mathrm{a}$ & 3 \\
\hline & Untreated control & $2.7 \mathrm{a}$ & $0.1 \mathrm{a}$ & 0 \\
\hline \multirow{3}{*}{2008} & Routine & $<1 \mathrm{a}$ & $1.6 \mathrm{a}$ & 6 \\
\hline & VNIIFBlight & $1.0 \mathrm{a}$ & $1.5 \mathrm{a}$ & 5 \\
\hline & Untreated control & $39.0 \mathrm{~b}$ & $16.4 \mathrm{~b}$ & 0 \\
\hline
\end{tabular}

Note. ${ }^{*}$ - for each year, the difference between the values marked by the same letters is not significant at $P_{0.05}$.

In 2005 and 2007, the weather was hot and dry, and late blight development was reduced. We did not observe any significant disease development for the compared fungicide treatments. Due to the reduced incidence of late blight, all fungicide applications were rather needless, but the use of the decision support system VNIIFBlight reduced the number of fungicide treatments as compared with the routine scheme and, therefore, saved money. According to the decision support system VNIIFBlight recommendations, the total number of applications in these seasons was reduced by $50 \%$. In general, the use of the decision support system VNIIFBlight in the four-year field trials resulted in a 17 $62 \%$ decrease of a fungicide input as compared to the routine program of treatment.

"Virtual" trials. As we expected, the use of the decision support system VNIIFBlight in both "virtual" trials resulted in a significantly lower number of fungicide treatments compared with the seven-day routine scheme (Tables 2 and 3). The first trial demonstrated that, though late blight risks fluctuated from year to year, the average frequency of the late blight-favourable days in Vilnius, Kaunas and Kaliningrad regions was higher than in Vologda region. The same parameter of Vologda region was higher than that of Moscow, Kazan and Dotnuva regions. This fact influenced the number of fungicide applications required according to the VNIIFBlight recommendations (Table 2). The "virtual" use of the decision support system VNIIFBlight over the six-year period of the trial for Vilnius region resulted in an average decrease in the fungicide application for susceptible and resistant potato cultivars by $19 \%$ and $43 \%$, respectively, as compared to the routine seven-day scheme. In the Kazan region, this decrease reached $90 \%$ for both groups of cultivars. In some years, the number of fungicide treatments recommended by the decision support system VNIIFBlight for the Vilnius, Kaunas, Kaliningrad and Vologda regions was the same or almost the same as compared with the routine program.

For the whole studied period, the maximum decrease in the use of fungicides was obtained in Kazan region, where severe drought significantly suppressed late blight development. In Lithuania, Dotnuva region significantly differed from two other regions for all studied seasons. In spite of rather small distances between the three regions $(60-160 \mathrm{~km})$, weather conditions in Dotnuva region were less favourable for the late blight development as compared with Vilnius and Kaunas regions. As a result, in Vilnius region, the recommended average number of seasonal fungicidal treatments made 5.6 and 4.0 for susceptible and resistant cultivars, respectively; in Kaunas region, the corresponding number of treatments made 4.6 and 3.5, respectively; finally, the number of treatments recommended for Dotnuva region, made 2.2 and 2.2, respectively. Earlier it was shown that, due to the more arid climate, the frequency of the late blight epidemics in Dotnuva, located in Central Lithuania, was significantly lower than that for Elmininkai (approximately $100 \mathrm{~km}$ to the north-east of Dotnuva). Only two out of ten years in Dotnuva were characterized by rainfall amounts exceeding the average value for Lithuania, whereas Elmininkai had six such years out of the ten years studied (Ronis et al., 2007).

In the second "virtual" trial we monitored fiveday weather forecasts in several geographic regions during the period between 15 June, 2014 and 5 August, 2014 to determine late blight-favourable days and calculate the recommended dates for fungicide applications. As it was expected, the calculated number of fungicidal treatments for compared sites depended on the number of late blightfavourable periods, the uniformity of the distribution of these periods within the vegetation season, and the level of the late blight susceptibility of potato cultivars. The maximum number of recommended treatments was observed if late blight-favourable periods were uniformly distributed. If these periods formed separate groups, the number of recommended treatments decreased, since one treatment was efficient for 2-3 periods.

For all regions studied, the use of the decision support system VNIIFBlight resulted in a significant decrease in the fungicide use (Table 3 ). The routine program of fungicide application provided for seven treatments within the period of observations. At the same time, the average number of treatments recommended by the decision support system VNIIFBlight for the same period in compared treatments varied from 2.2 to 3.2. The maximum decrease in fungicide applications was obtained in Kazan, Bryansk and Kiev regions where late blight suppression was registered. In order to protect the potato crop, cultivated without any irrigation, no more than one fungicide treatment was required. The minimum decrease in fungicide use was registered for rainy Lelystad, where a total of five treatments were recommended. 
Table 2. Number of fungicide applications recommended by the decision support system VNIIFBlight and seven-day routine scheme in four geographic regions for the period of 15 June-5 August

\begin{tabular}{|c|c|c|c|c|c|}
\hline \multirow[t]{2}{*}{$\begin{array}{c}\text { Year of } \\
\text { observation }\end{array}$} & \multirow{2}{*}{$\begin{array}{c}\text { Number } \\
\text { of rainy } \\
\text { days }\end{array}$} & \multicolumn{2}{|c|}{$\begin{array}{l}\text { Number of fungicide applications recommended } \\
\text { by the decision support system VNIIFBlight }\end{array}$} & \multicolumn{2}{|c|}{$\begin{array}{l}\text { Decrease in the number of treatments } \\
\text { as compared with } \\
\text { the seven-day routine scheme } \%\end{array}$} \\
\hline & & susceptible cultivars* & resistant cultivars $* *$ & susceptible cultivars & resistant cultivars \\
\hline \multicolumn{6}{|c|}{$\begin{array}{l}\text { Kaliningrad region } \\
\end{array}$} \\
\hline 2009 & 20 & 3 & 3 & 58.0 & 58.0 \\
\hline 2010 & 18 & 3 & 2 & 58.0 & 71.4 \\
\hline 2011 & 26 & 4 & 4 & 42.9 & 42.9 \\
\hline 2012 & 38 & 7 & 5 & 0 & 28.6 \\
\hline 2013 & 29 & 4 & 2 & 42.9 & 71.4 \\
\hline 2014 & 25 & 5 & 4 & 28.6 & 42.9 \\
\hline Average & 26.0 & 4.3 & 3.3 & 38.3 & 52.5 \\
\hline \multicolumn{6}{|c|}{ Vologda region } \\
\hline 2009 & 19 & 6 & 4 & 14.3 & 42.9 \\
\hline 2010 & 21 & 1 & 1 & 85.7 & 85.7 \\
\hline 2011 & 9 & 3 & 2 & 58.0 & 71.4 \\
\hline 2012 & 29 & 1 & 1 & 85.7 & 85.7 \\
\hline 2013 & 39 & 6 & 4 & 14.3 & 42.9 \\
\hline 2014 & 16 & 4 & 3 & 42.9 & 58.0 \\
\hline Average & 22.0 & 3.5 & 2.5 & 50.1 & 64.4 \\
\hline \multicolumn{6}{|c|}{ Moscow region } \\
\hline 2009 & 28 & 4 & 3 & 42.9 & 58.0 \\
\hline 2010 & 18 & 1 & 1 & 85.7 & 85.7 \\
\hline 2011 & 33 & 4 & 4 & 42.9 & 42.9 \\
\hline 2012 & 24 & 3 & 2 & 58.0 & 71.4 \\
\hline 2013 & 29 & 3 & 3 & 58.0 & 58.0 \\
\hline 2014 & 25 & 2 & 1 & 71.4 & 85.7 \\
\hline Average & 26.2 & 2.8 & 2.3 & 59.8 & 66.9 \\
\hline \multicolumn{6}{|c|}{ Kazan region } \\
\hline 2009 & 18 & 1 & 1 & 85.7 & 85.7 \\
\hline 2010 & 4 & 0 & 0 & 100 & 100 \\
\hline 2011 & 9 & 0 & 0 & 100 & 100 \\
\hline 2012 & 12 & 1 & 1 & 85.7 & 85.7 \\
\hline 2013 & 18 & 1 & 1 & 85.7 & 85.7 \\
\hline 2014 & 16 & 1 & 1 & 85.7 & 85.7 \\
\hline Average & 12.8 & 0.6 & 0.6 & 90.3 & 90.3 \\
\hline \multicolumn{6}{|c|}{ Dotnuva region } \\
\hline 2009 & 20 & 3 & 3 & 58.0 & 58.0 \\
\hline 2010 & 18 & 2 & 2 & 71.4 & 71.4 \\
\hline 2011 & 21 & 2 & 2 & 71.4 & 71.4 \\
\hline 2012 & 20 & 2 & 2 & 71.4 & 71.4 \\
\hline 2013 & 19 & 2 & 2 & 71.4 & 71.4 \\
\hline 2014 & 14 & 2 & 2 & 71.4 & 71.4 \\
\hline Average & 18.7 & 2.2 & 2.2 & 69.2 & 69.2 \\
\hline \multicolumn{6}{|c|}{ Kaunas region } \\
\hline 2009 & 32 & 5 & 4 & 28.6 & 42.9 \\
\hline 2010 & 32 & 6 & 4 & 14.3 & 42.9 \\
\hline 2011 & 35 & 5 & 3 & 28.6 & 58.0 \\
\hline 2012 & 33 & 5 & 4 & 28.6 & 42.9 \\
\hline 2013 & 23 & 4 & 3 & 42.9 & 58.0 \\
\hline 2014 & 34 & 3 & 3 & 58.0 & 58.0 \\
\hline Average & 31.5 & 4.6 & 3.5 & 33.5 & 50.3 \\
\hline \multicolumn{6}{|c|}{ Vilnius region } \\
\hline 2009 & 21 & 6 & 4 & 14.3 & 42.9 \\
\hline 2010 & 32 & 6 & 4 & 14.3 & 42.9 \\
\hline 2011 & 34 & 6 & 4 & 14.3 & 42.9 \\
\hline 2012 & 37 & 5 & 4 & 28.5 & 42.9 \\
\hline 2013 & 30 & 5 & 4 & 28.5 & 42.9 \\
\hline 2014 & 38 & 6 & 4 & 14.3 & 42.9 \\
\hline Average & 32.0 & 5.6 & 4 & 19.0 & 42.9 \\
\hline
\end{tabular}

* - late blight resistance index $<5, * *$ - late blight resistance index $\geq 5$

In some cases, the availability of irrigation increased the recommended frequency of a fungicide use. For example, when a five-day irrigation scheme was applied in (a) Charlottetown and (b) Tyumen, Bryansk, Kiev, and Lelystad, the number of recommended fungicide applications increased by one or two, respectively as compared with the "no irrigation" case.
Taken together, the results of the performed "virtual" trials demonstrate that the use of the decision support system VNIIFBlight sometimes excluded the necessity of the fungicide application - Kazan region in 2010 and 2011 (Table 2) and Kiev region in 2014 (Table 3). In some cases, the number of recommended treatments was equal to or close to that recommended by 
Table 3. Number of fungicide applications recommended by the decision support system VNIIFBlight or routine scheme for ten climatic regions within the period of 15 June-5 August, 2014

\begin{tabular}{|c|c|c|c|c|c|}
\hline \multirow{3}{*}{ Region } & \multicolumn{4}{|c|}{$\begin{array}{c}\text { Number of fungicide treatments recommended by } \\
\text { the decision support system VNIIFBlight }\end{array}$} & \multirow{3}{*}{$\begin{array}{c}\text { Number of } \\
\text { fungicide treatments } \\
\text { recommended by } \\
\text { a seven-day routine } \\
\text { scheme }\end{array}$} \\
\hline & \multicolumn{2}{|c|}{ Susceptible cultivars* } & \multicolumn{2}{|c|}{ Resistant cultivars $* *$} & \\
\hline & $\begin{array}{l}\text { without } \\
\text { irrigation }\end{array}$ & $\begin{array}{c}\text { with } \\
\text { irrigation } * * *\end{array}$ & $\begin{array}{l}\text { without } \\
\text { irrigation }\end{array}$ & $\begin{array}{l}\text { with } \\
\text { irrigation }\end{array}$ & \\
\hline Tumen & 4 & 5 & 3 & 4 & 7 \\
\hline Kazan & 1 & 1 & 1 & 1 & 7 \\
\hline Moscow & 3 & 3 & 2 & 2 & 7 \\
\hline Brjansk & 1 & 2 & 1 & 1 & 7 \\
\hline Kaliningrad & 3 & 3 & 2 & 2 & 7 \\
\hline Yuzhno-Sakhalinsk & 4 & 4 & 4 & 4 & 7 \\
\hline Kiev (Ukraine) & 0 & 2 & 0 & 2 & 7 \\
\hline Warsaw (Poland) & 2 & 2 & 2 & 2 & 7 \\
\hline Lelystad (Netherlands) & 5 & 6 & 5 & 5 & 7 \\
\hline Charlottetown (Canada) & 2 & 4 & 2 & 4 & 7 \\
\hline Average & 2.5 & 3.2 & 2.2 & 2.7 & 7.0 \\
\hline
\end{tabular}

* - late blight resistance index $<5$; ** - late blight resistance index $\geq 5 ; * * *$ - irrigation (spraying) is performed every five days

the routine scheme - Kaliningrad region in 2012 (Table 2) and Lelystad region in 2014 (Table 3). However, in most cases, the use of the decision support system VNIIFblight made it possible to significantly decrease the number of fungicide treatments as compared with the routine scheme. For all seasons included in Tables 2 and 3, the use of the decision support system VNIIFBlight for susceptible and resistant potato cultivars would save about $50 \%$ and $60 \%$ of the total fungicides used, respectively.

In contrast to the majority of the decision support systems used in Europe and North America, the decision support system VNIIFBlight is more available for practical use, since it does not require the presence of a stationary weather station in a farmer's field. To use this decision support system, a farmer should have access to the Internet to obtain a 5-day weather forecast; using these data and a simple calculator, a farmer can determine the optimal date for a fungicidal treatment of his potato field.

\section{Conclusion}

The use of the decision support system VNIIFBlight to determine the dates of fungicidal treatments for the late blight control has some advantages over the routine scheme of treatment. This decision support system allows a user to spray the potato crop exactly when the weather forecast is favourable for the late blight development. In addition, this decision support system takes into account the late blight resistance level of the potato cultivars used. According to the results of the field trials, performed in Moscow region, Russia, and "virtual" trials, calculated for 11 different regions of Russia, Lithuania, Ukraine, Poland, the Netherlands, and Canada, the use of the decision support system VNIIFBlight enables reduction of the number of fungicidal treatments in potato. Four-year field trials showed that the both protection schemes compared provided a similar reduction of the late blight severity in relation to the untreated control. At the same time, during the seasons with a severe late blight development (2004 and 2008), the number of fungicidal treatments recommended by the decision support system VNIIFBlight was lower by $62 \%$ and $17 \%$, respectively, as compared to the routine protection scheme. In 2005 and 2007, when weak disease development was recorded, this reduction was $50 \%$. The reduction of the fungicide application frequency was also observed in the majority of "virtual" trials. In two cases, the use of this decision support system completely excluded the necessity of fungicide use (Kazan region, 2010-2011, and Kiev region, 2014), whereas in some other cases the number of recommended treatments was equal or close to that of the routine protection scheme (Kaliningrad region, 2012, and Lelystad region, 2014). For all tested regions and seasons, the use of the decision support system VNIIFBlight for susceptible and resistant potato cultivars would allow a farmer to save about $50 \%$ and $60 \%$ of the total fungicides used, respectively.

Received 22062015

Accepted 29102015

\section{References}

Benbrook C. M., Sexson D. L., Wyman S. A., Stevenson W. R., Lynch S., Wallendal J., Diercks S., Van Haren R., Granadino C. A. 2002. Developing a pesticide risk assessment tool to monitor progress in reducing reliance on high-risk pesticides. American Journal of Potato Research, 79 (3): 183-200 http://dx.doi.org/10.1007/BF02871934

Bǿdker L., Nielsen B. J. 2001. Preventive and curative effect of fungicides against late blight under field conditions. PPOSpecial Report, 7: 261-265

Cox A. E., Large E. C. 1960. Potato late blight epidemics throughout the world. USDA. Agriculture Handbook No. 174

Dospekhov B. A. 1984. Field experimentation: statistical procedures. Moscow, Russia, $352 \mathrm{p}$.

Filippov A. V. 2012. Potato late blight. Zashchita i karantin rastenii, 5 (S): 61-87 (in Russian)

Filippov A. V., Kuznetsova M. A., Rogozhin A. N., Spiglazova S., Smetanina T. I., Derenko T. A., Statsyuk N. V. 2009. Efficacy of the VNIIFBlight decision support system in the control of potato late blight in Russia. PPO-Special Report, 13: 243-250

Fry W. E. 1978. Quantification of general resistance of potato cultivars and fungicide effects for integrated control of potato late blight. Phvtopathologv. 68: 1650-1655 http://dx.doi.org/10.1094/Phyto-68-1650

Fry W. E., Apple A. E., Bruhn J. A. 1983. Evaluation of potato late blight forecasts modified to incorporate host resistance and fungicide weathering. Phytopathology, 73: 1045-1059 http://dx.doi.org/10.1094/Phyto-73-1054

Gurevich B. I., Filippov A. V., Tverskoy D. L. 1977. Comparison of two methods for the estimation of potato harvest losses caused by the late blight of leaves. Sel'skohozyaistvennaya Biologiya, 12 (3): 444-448 (in Russian)

Hansen J. G., Andersson B., Bain R., Besenhofer G., Richie F., Bicena L., Bugiani R., Çakir E., Cooke L., Dubois L., Filipov A., Hannukkala A., Hausladen H., Hausvater E., 
Heldak J., Hermansen A., Kapsa J., Koppel M., Lebecka R., Lees A., Musa T., Nugteren W., Ronis A., Schepers H., Spits H., Verbeke P. V. 2009. The development and control of Phytophthora infestans in Europe in 2007 and 2008. PPO-Special Report, 13: 11-30

Hansen J. G., Andersson B., Bain R., Lees A., Ritchie F., Kildea S., Cooke L., Filippov A., Hannukkala A., Hausladen H., Hausvater E., Heldak J., Vrabcek P., Hermansen A., Nærstad R., Kapsa J., Koppel M., Musa T., Ronis A., Schepers H., Vogelaar K., Vanhaverbeke P., Kanetis L. 2014. The development and control of Late Blight (Phytophthora infestans) in Europe in 2012. PPOSpecial Report, 16: 11-25

Hu T., Zhao Z., Zhou D., Zhu J., Cao K. 2014. Chemical control strategy of potato late blight based on the DSS "Chinablight”. PPO-Special Report, 16: 139-145

Kessel G. S. T., Spruijt J., Evenhuis A., Van Bekkum P. J., Schepers H. T. A. M. 2010. Experimental control strategies reducing the fungicide input at practical scale. PPO-Special Report, 14: 199-203

Nielsen B. S., Bǿdker L., Hansen J. G. 2010. Control of potato late blight using a dose model to adjust fungicide input. PPO-Special Report, 14: 187-192

Ronis A., Tamošiūnas K. 2005. The comparison of the decision support systems "NegFry" and "PLANT Plus" for the control of late blight in Lithuania. Sodininkyste ir daržininkystè, 24 (3): 362-370

Ronis A., Rainys K., Semaškienė R., Lazauskas S. 2007. Potato late blight in Lithuania. PPO-Special Report, 12: 303-308

Runno-Paurson E., Ronis A., Hansen M., Aav A., Williams I. H. 2015. Lithuanian populations of Phytophthora infestans revealed a high phenotypic diversity. Journal of Plant Diseases and Protection, 122 (2): 57-65
Schepers H. T. A. M. 2004. Decision support systems for integrated control of late blight. Plant Breeding and Seed Science, 50: 57-61

Schepers H. T. A. M., Evenhuis A., Spits H. G. 2009. Strategies to control late blight in potatoes in Europe. Acta Horticulturae. 834: 79-82

http://dx.doi.org/10.17660/ActaHortic.2009.834.7

Shykla Y., Arora A. 2001. Transplacental carcinogenic potential of the carbamate fungicide mancozeb. Journal of Environmental Pathologv. Toxicology and Oncology, 20 (2): 127-131 http://dx.doi.org/10.1615/ jenvironpatholtoxicoloncol.v20.i2.70

Small I. M., Joseph L., Fry W. E. 2013. Evaluation of the blight decision support system for the integrated management of potato and tomato late blight. Phytopathology, 103: 134-135

Spits H., Evenhuis B., Schepers H. 2007. Fungicide dose rate and cultivar resistance results of five years of field experiments in the Netherlands. PPO-Special Report, 12: 165-170

Starodub I. L., Gurevich B. I. 1989. The use of a five-day weather forecast to calculate chances of the potato late blight outbreak. Meteorologiya i gidrologiya, 7: 28-36 (in Russian)

Twining S., Clarke J., Cook S., Ellis S., Gladders P., Ritchie F., Wynn S. 2009. Pesticide availability for potatoes following revision of Directive 91/414/EEC: Impact assessments and identification of research priorities. <http://www.potato. org.uk/sites/default/files/publication_upload/20092

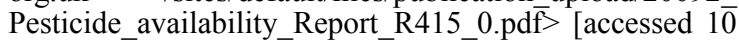
06 2015]

Van der Plank J. E. 1963. Plant diseases: epidemics and control. New York, USA, $349 \mathrm{p}$.

Wander I. G. N., Spits H. G., Kessel G. S. T. 2006. Exploiting potato late blight cultivar resistance using DSS's: four years of field experiments. PPO-Special Report, 11: 113-119

ISSN 1392-3196 / e-ISSN 2335-8947

Zemdirbyste-Agriculture, vol. 102, No. 4 (2015), p. 449-456

DOI $10.13080 / \mathrm{z}-\mathrm{a} .2015 .102 .058$

\title{
Sprendimų priẻmimo kompiuterinès programos efektyvumo nustatymas, siekiant sumažinti bulvių pasèlių purškimą fungicidais
}

\author{
A. Filippov ${ }^{1}$, A. Rogozhin ${ }^{1}$, M. Kuznetsova ${ }^{1}$, N. Statsyuk ${ }^{1}$, A. Ronis ${ }^{2}$, H. W. (Bud) Platt ${ }^{3}$ \\ ${ }^{1}$ Rusijos fitopatologijos mokslinių tyrimų institutas \\ ${ }^{2}$ Lietuvos agrarinių ir miškų mokslų centro Žemdirbystès institutas \\ ${ }^{3}$ Kanados žemès ūkio augalų ir gyvulių tyrimų centras
}

\section{Santrauka}

Kompiuterinė programa VNIIFBlight skirta nustatyti, ar susidariusios meteorologinès sąlygos yra tinkamos bulvių marui plisti. Siekiant nustatyti kuo tikslesnę fungicidų purškimo datą, buvo naudota kompiuterinė programa VNIIFBlight, sudaryta iš penkių dienų meteorologinès prognozės ir informacijos apie bulvių veislių atsparumą bulvių marui. Atliekant lauko ir virtualius eksperimentus kompiuterinės programos efektyvumas buvo lyginamas su ịprastine septinių dienų purškimo programa. Lauko eksperimentai buvo atlikti 2004-2008 m. Maskvos regione, virtualūs - 2009-2014 m. keturiuose Rusijos, trijuose Lietuvos ir viename Kanados, Ukrainos, Lenkijos bei Olandijos regionuose.

Atlikus lauko eksperimentus nustatyta, kad 2004 ir 2008 m., kai bulvių maras intensyviai plito, derliaus nuostoliai neapsaugotame kontroliniame variante sudare 62 ir 39 proc., o 2005 ir 2007 m., fungicidus panaudojus pagal ịprastinę schemą, derliaus nuostoliai neviršijo 8,2 proc. Kai buvo nustatytas silpnas bulvių maro plitimas, visuose tirtuose, įskaitant kontrolinį, variantuose derliaus nuostoliai neviršijo 3 proc. Visais tyrimų metais kompiuterine programa VNIIFBlight esmingai sumažino fungicidų purškimų skaičių, palyginus su ịprastine purškimo programa. Purškimų skaičiaus sumažèjimas 2004, 2005, 2007 ir 2008 m. sudarė atitinkamai 62, 50, 50 ir 17 proc.

Virtualių eksperimentų rezultatai parodè, kad taikant kompiuterinę programą VNIIFBlight, marui jautrių veislių bulvių purškimų fungicidais skaičių galima būtų sumažinti vidutiniškai 50 proc., o bulvių marui atsparių veislių 60 proc., palyginus su įprastine purškimo programa.

Reikšminiai žodžiai: bulvių maras, fungicidų purškimas, matematinis modelis. 